$88: 690$

$<$ 症例報告 $>$

$$
\begin{gathered}
\text { アルコール常用者にみられたアセトアミノフェンによる } \\
\text { 急性肝不全の } 1 \text { 例 }
\end{gathered}
$$

清水 勝* 時田 元* 越野 陽介**** 星山 直基*

山田 昌夫* 高橋善弥太** 西川 佳秋***

要 旨：アセトアミノフェン大量服用による急性肝不全はよく知られている。今回著者らは40

墄，女性のアルコール常用者が，アセトアミノフェン4.8g (セデス $\mathrm{A}$ 錠60錠) をアルコール

とともに服用し，急性肝不全で死亡した 1 例を経験した。剖検肝重量は $750 \mathrm{~g}$ ，広沉性部位によ

り悪広汎性肝細胞性壞死が存在し病理学的に急性肝萎縮と診断された。本例の服用フセトアミ

ノフェン量は $4.8 \mathrm{~g}$ と比較的少量であるが, 急性肝不全をきたした原因として，1）フルコール常

用者であったこと，2）アセトアミノフェンがカフェインとの合剤で服用されて抣りその相互作

用が考光られ文献的に考察した。アセトアミノフェンの使用にあたっては，予想以上に重篤な

肝障害発生の危険もあり注意が必要である。

卖引用語：アセトフミノフェン 急性肝不全 急性肝萎縮 アルュール

カフェイン

緒言

急性肝不全（劇症肝炎）の原因は，本邦では大部分 がウイルス性であるが，薬風による報告例る少なから ずみられる1．鎮痛解熱剤であるアセトフミノフェン は，速效性があり副作用も少ない点から一般に使用さ れる機会も多い.1966年 Davidson ら² は本剂の大量投 与により肝に致死的な肝壊死をきたした 2 例を報告し ているか，欧米とくに英国では自殺の目的で服用され た急性肝不全例が多〈みられる゙．本邦でもアセトア ミノフェンの大量服用による急性肝不全例の報告がみ られるが，一方たとえ少量ですアルコール摂取者が服 用すると思わぬ重篤な肝障害をきたすことが知られて (いる⿱

今回著者らは，40歳，女性のアルコール常用者が自 殺の目的で,つセトアミノフェン $4.8 \mathrm{~g}$ をカフェインと の合剤としてアルコールとともに服用し, 急性肝不全 をきたし死亡した 1 例を経験したので，若干の文献的 考察を加えて報告する。

\footnotetext{
*岐阜県立岐阜病院消化器科

** 同 名誉院長

***同 病理診断部

****現 岐阜大学第 1 内科

〈受付日1988年12月12日 $>$
}

\section{症 例}

症例. 40歳，女性. 金属会社パート勤務。

主訴 : 意識障害.

家族歴：父, 高血圧症.

既往歴：特記事項なし。

現病歴：元来酒好きで 1 日 3 合前後の领酒を続けて いた.

昭和62年 5 月 6 日内緣の夫との不和むあり，七デス $\mathrm{A} \otimes$ 錠60錠(アセトアミノフェン4.8g) をアルコールと ともに服用した．翌日 7 日午前 1 時頃帰宅した内縁の 夫に, 意識消失状態になっているところを発見された。 救急車で某病院に運ばれ，胃洗浄を受けた後当院救命 救急センターに紹介入院した。

入院時現症：意識レベル III-3，脈拍124/分，整，㗨 張ほぼ良好. 血王 $140 / 90$ ，呼吸数 $18 /$ 分. 結膜に負血， 黄㾝ともに認めず. 肺野聴診上両側に湿性ラ音聴取, 心音清明. 腹部平坦, 肝・脾触知せず。腹水徵候なし。 下肢浮腫認めず。

入院時検查所見：入院時の主な検查所見を Table 1 に示した. S-GOT $653 \mathrm{IU} / l$, S-GPT $174 \mathrm{IU} / l, \mathrm{LDH}$ $1,750 \mathrm{IU} / l, \mathrm{CPK} 8,810 \mathrm{IU} / l$ と増加しており,ブロト ロンビン時間は $25 \%$ と活性低下を認め重篤な肝障害の 存在が示唆された. HBs 抗原, IgM 型抗 HBc 抗体, IgM 型抗 HA 抗体はともに陰性であった。 なお血中の 
Table 1 Laboratory data.

\begin{tabular}{|c|c|c|c|}
\hline \multicolumn{2}{|l|}{ Urinalysis } & \multicolumn{2}{|c|}{ Blood chemistry } \\
\hline Protein & $(-)$ & T.Bil & $1.4 \mathrm{mg} / \mathrm{d} l$ \\
\hline Sugar $\quad 1 \%$ & (卅) & GOT & $653 \mathrm{IU} / l$ \\
\hline Occult blood & 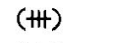 & GPT & $174 \mathrm{IU} / l$ \\
\hline Urobilinogen & $( \pm)$ & LDH & $1750 \mathrm{IU} / l$ \\
\hline Bilirubin & $(-)$ & CPK & $8810 \mathrm{IU} / l$ \\
\hline \multicolumn{2}{|l|}{ Blood analysis } & $\gamma$-GTP & $121 \mathrm{IU} / l$ \\
\hline RBC $337 x$ & $337 \times 10^{4}$ & ALP & $260 \mathrm{IU} / l$ \\
\hline WBC & 7100 & Ch-E & $2.6 \mathrm{IU} / l$ \\
\hline $\mathrm{Hb}$ & $12.3 \mathrm{~g} / \mathrm{d} l$ & ZTT & $7 \mathrm{U}$ \\
\hline $\mathrm{Ht}$ & $36.8 \%$ & TTT & $3 \mathrm{U}$ \\
\hline Plat $16.7 \times$ & $16.7 \times 10^{4}$ & $\mathrm{TP}$ & $6.2 \mathrm{~g} / \mathrm{d} l$ \\
\hline \multicolumn{2}{|c|}{ Coagulative examination } & Alb & $3.7 \mathrm{~g} / \mathrm{d} l$ \\
\hline PT 19.3 & $19.3 \sec (11.2)$ & TG & $8 \mathrm{mg} / \mathrm{d} l$ \\
\hline $\mathrm{TT}$ & $76.5 \%$ & T-Chol & $112 \mathrm{mg} / \mathrm{d} l$ \\
\hline HPT & $28.9 \%$ & Sugar & $593 \mathrm{mg} / \mathrm{d} l$ \\
\hline APTT 47.7 & $47.7 \sec (30.8)$ & Amylase & $146 \mathrm{U}$ \\
\hline \multicolumn{2}{|c|}{ Fibrinogen $112 \mathrm{mg} / \mathrm{d} l$} & $\mathrm{NH}_{3}$ & $35 \mathrm{mg} / \mathrm{d} l$ \\
\hline FDP $\quad 20$ & $20-40 \mu \mathrm{g} / \mathrm{m} l$ & CRN & $1.4 \mathrm{mg} / \mathrm{d} l$ \\
\hline \multicolumn{2}{|c|}{ Serological examination } & Urea-N & $17.7 \mathrm{mg} / \mathrm{d} l$ \\
\hline \multicolumn{2}{|c|}{ HBsAg $\quad(-)$} & $\mathrm{Na}$ & $131 \mathrm{mEq} / l$ \\
\hline \multicolumn{2}{|c|}{ IgM anti-HAV $(-)$} & $\mathrm{K}$ & $4.1 \mathrm{mEq} / l$ \\
\hline \multicolumn{2}{|c|}{ IgM anti-HBc $(-)$} & $\mathrm{Cl}$ & $94 \mathrm{mEq} / l$ \\
\hline AFP & $.3 \mathrm{ng} / \mathrm{m} l$ & & \\
\hline
\end{tabular}

アセトフミノフェン濃度は247.2 $\mu \mathrm{g} / \mathrm{m} l$ であった.

経過：重篤な肝障害を合併したアセトアミノフェン による急性中毒と診断し, まずN-アセチルシステイン (ムコフィリン®) 初回量 $140 \mathrm{mg} / \mathrm{kg}$ を鼻腔ゾンデよ り，以後 4 時間おきに半量を17回注入した。 また特殊 組成アミノ酸製剂の点滴静中および血浆交換療法を開 始した。第 1 回目の血浆交換療法中より体動激しくな り，呼び掛けに反応するようになった，血浆交換療法 終了後，入院13時間後にはほぼ覚醒し会話も可能に なった.しかし Fig. 1に図示したごとく，入院 2 日目 にはS-GOT $8,500 \mathrm{IU} / l$, S-GPT $1,517 \mathrm{IU} / l$, 総ビリ ルビン $5.3 \mathrm{mg} / \mathrm{d} l$ と著増した. プロトロンビン時間は 10\%以下へ低下した。血浆遊離アミノ酸分析では入院 2 日目，5日目のメチオニンはそれぞれ $93.2 \mathrm{nMol} /$ $\mathrm{m} l, 496.5 \mathrm{nMol} / \mathrm{m} l$ と著増した(Table 2). 意識レべ ルは一度改善を認めたものの，入院 3 日目には訮性昏 睡II度になり，同日夕方にはIV度に陥った．血烘交換 療法を続けたが，肝性脳症の改善を認めず (Fig. 1)， 肺炎, 肺らっ血, DIC, 消化管出血を合併し入院 7 日目 （昭和62年 5 月13日）に死亡した.

剖検所見：肝重量は750g で淡黄緑色調を呈し, 肉眼 的に小葉構造は不鮮明であった (Fig. 2). 組織学的に

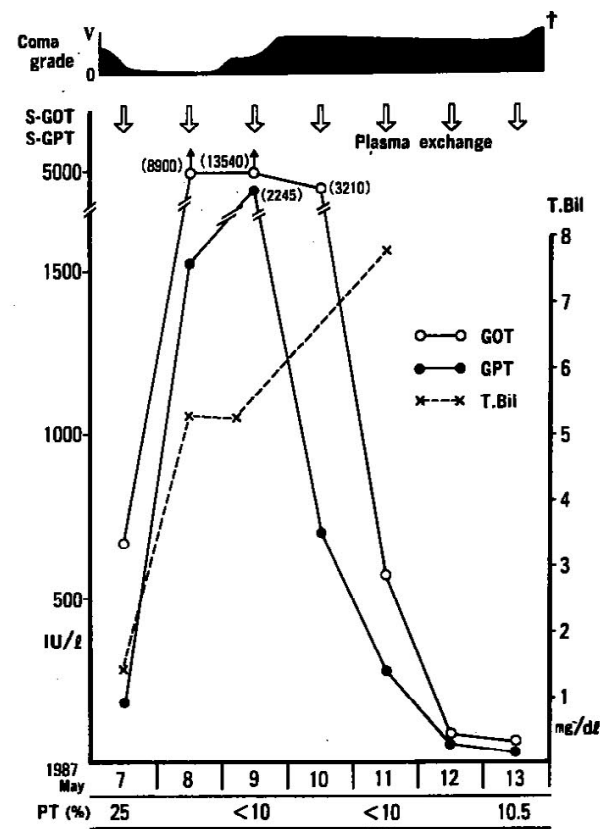

Fig. 1 Clinical course.

Table 2 Laboratory data.

\begin{tabular}{l|l|l}
\hline & \multicolumn{1}{|c|}{8, May } & \multicolumn{1}{c}{11, May } \\
\hline Valine & $688.2 \mathrm{nMOL} / \mathrm{m} l$ & $477.4 \mathrm{nMOL} / \mathrm{m} l$ \\
Leucine & 379.7 & 213.3 \\
Isoleucine & 260.7 & 132.7 \\
Tyrosine & 50.4 & 335.1 \\
Phenylalanine & 309.6 & 651.4 \\
Methionine & 93.2 & 496.9 \\
Lysine & 760.4 & 2727.8 \\
Histidine & 439.0 & 1064.7 \\
Arginine & 18.0 & 840.6 \\
\hline
\end{tabular}

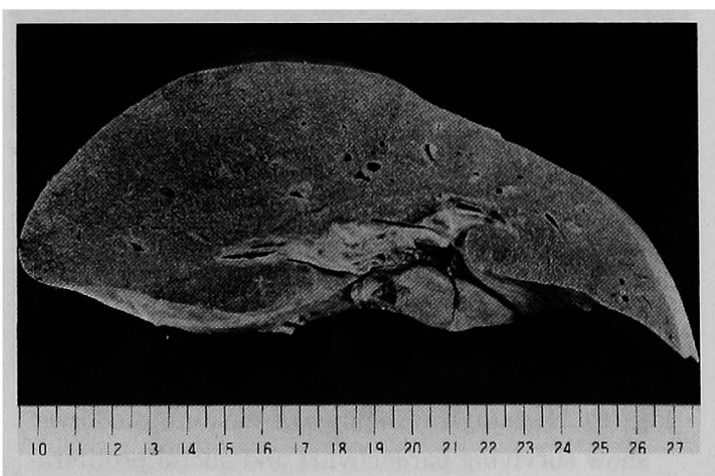

Fig. 2 The autopsied liver was markedly atrophic and its weight was $750 \mathrm{~g}$. 


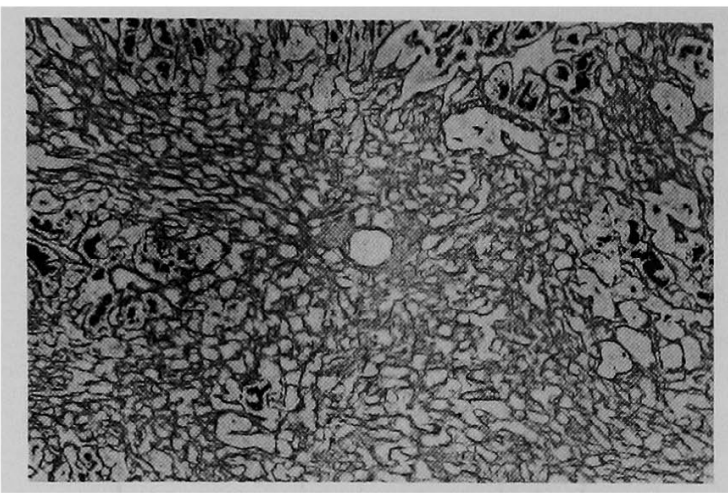

Fig. 3 Histological findings of the autopsied liver show collapse and condensation of reticulin (reticulin stain, $\times 100$ )

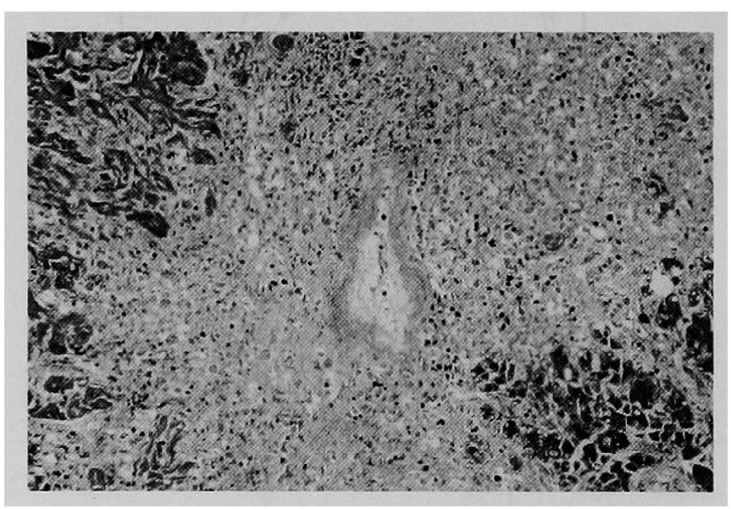

Fig. 4 Histological findings of the autopsied liver show massive hepatic cell necrosis in centrilobular areas without inflammatory cell infiltration (H-E stain, $\times 100$ )

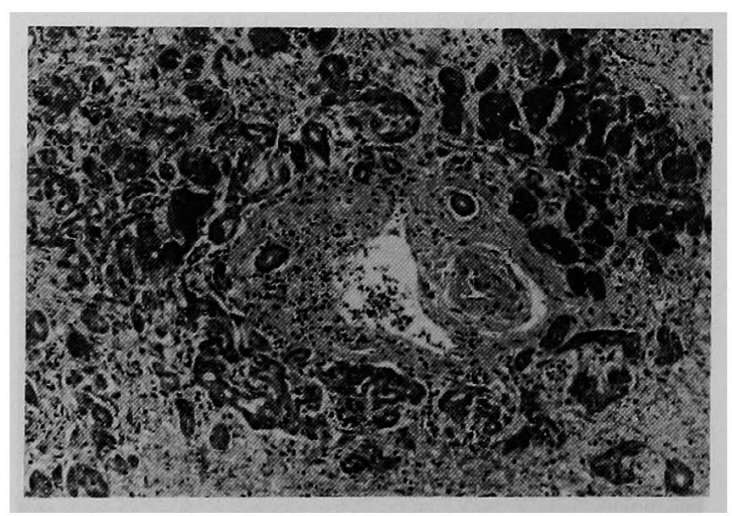

Fig. 5 Histological findings of the autopsied liver show surviving parenchyma and ductal proliferation of liver cells in the periportal areas (H-E stain, $\times 100$ )
は正常な肝細胞構造は破壊され, 細網線維構造の虚脱 (Fig. 3)がみられた。 中心静脈には変性像が観察され, 肝細胞は中心静脈周辺から辺縁部にかけて広汎性, 部 位によっては亜広汎性壊死に陷っていた (Fig. 4). ま た門脈域周辺では肝細胞の偽胆管様再生 (Fig. 5)がみ られ，核分裂像も観察された。病理学的には急性肝萎 絔と診断された。部検診断：(1)急性肝萎縮 $(750 \mathrm{~g}$ ), (2) $5 っ$ 血性肺水腫十気管支肺资十肺出血（左1,065g, 右 $1,095 \mathrm{~g}$ ), (3)心筋梗塞 (左室側壁心内膜下 $390 \mathrm{~g}$ ), (4)膵 梗塞 $(140 \mathrm{~g}$ ), (5)両側副腎皮質壊死 (左 $4.8 \mathrm{~g}$, 右 $6.5 \mathrm{~g}$ ), (6)全身諸臓器のうっ血およぴ出血傾向，(7)腹水 (460 $\mathrm{m} l$ ), (8)左卵巣卵胞垔胞, (9)副脾.

$$
\text { 考案 }
$$

アセトアミノフェン大量服用により致死的な肝細胞 壊死2)が発生するが，欧米とくに英国では自殺目的で 服用され本剤による劇症訮炎が多くみられる゙!

まずアセトアミノフェンの生体内代謝 ${ }^{7 \sim 9)}$ であるが, 大部分はグルクロン酸抱合，硫酸抱合を受けて毒性の ない物質になり尿中に排泄されて肝障害をきたさな い.しかし一部分は肝ミクロゾーム分画のチトクロー ムP-450を介する薬物代謝系 (mixed-function oxidase) で代謝 (水酸化) され，N-hydroxyl-acetami nophenを介して反応性に富む中間代謝産物 (reactive intermediate, N-acetylimidoquinone) が生成される が, この物質も肝内の glutathione-S-transferase に よってグルタチオン抱合をうけ, 解毒化されメルカプ ッール酸として尿中に排泄され肝障害をきたさないと 理解されている、しかしアセトアミノフェンが大量投 与されると, グルクロン酸抱合, 硫酸抱合が飽和状態 になるため，チトクロームP-450を介して代謝される ことになり，肝内のグルチオンが減少し，毒性のあ る中間代謝産物 N-acetylimidoquinone が大量に生成 されこれが肝細胞の構成蛋白と不可逆的共有結合し て重篤な訮障害が㟯起される。一般にアセトアミノ フェンによる重篤な肝障害は $10 \mathrm{~g}$ 以上の大量投与で発 生するとされているが ${ }^{8,10)}$, 本例のごとく $5 \mathrm{~g}$ 以下の比 較的少量服用でる発生するといら報告例むみられる. その原因として，1）アルュール摄取 ${ }^{4 \sim 6)}$ ，2）絶食状態 での服用 ${ }^{4,11)} ， 3$ ) 薬物常用者(フェノバルビタール), 4）カフェインとの合㓮13゙な゙があげられる.本邦です 安永ら”は38歳, 男性で少量のアセトフミノフェン （3.7g）をアルコールとともに服用し急性重症肝障害 を起こした 1 例を報告し，飲酒が重症肝障害惹起の上 で重要な因子であると考察している，動物実験では， 
急性エタノール投与ラットでは肝内グルタチオンが減 少するといら4).一方慢性エタノール投与ラットでは アセトアミノフェン投与後の還元型グルタチオンの消 費が元進するため，毒性ある中間代謝産物の産生増加 がいわれている14．著者らの症例では 1 日 3 合前後の フルコール常用者であり，またアルコールとともにア セトアミノフェンを服用したため，重篤な訮障害をき たしたと考えられる。

さらに本例ではアセトアミノフェンはセデス $\mathrm{A}$ 錠 といらカフェインとの合率として服用されているが， 阿部ら ${ }^{15)}$ はセデス $\mathrm{A}{ }^{\circledR 30}$ 錠フセトフミノフェンに換算 して2.4g という少量服用で広沉性肝細胞壊死をきた した 1 死亡例を報告している。野内ら ${ }^{131}$ は，アセトアミ ノフェン単独ではなく合剤として服用したことを重視 している。セデス $\mathrm{A}$ 錠は 1 錠中にエテンサミド200 $\mathrm{mg}$, アセトアミノフェン $80 \mathrm{mg}$, プロムワレリル尿素 $100 \mathrm{mg}$ ，無水カフェイン $25 \mathrm{mg}$ を含有しているが，野内 ら フェインとの相互作用を強調している，佐藤ら ラットを用いた実験で，アセトアミノフェン単独投与 群に比してアセトアミノフェンとカフェイン同時投与 群は，血清トランスアミナーゼの上昇も著明であり， また肝組織像にも著明な罣死がみとめられたと報告し ている、カフェインがフセトフミノフェンの肝細胞障 害を増強していることを示唆している。したがって本 例では，フルコール常用者がフルコールとともにアセ トアミノフェンをセデス $\mathrm{A}{ }^{\circledR}$ 錠といらカフェインとの 合剂の型で服用した点, さらに致死的な肝細胞の壊死 をきたしたと考えられた。アセトアミノフェンの投与， 服用にあたっては十分注意する必要があり本症例を報 告した。

本例はアセトアミノフェンによる急性肝不全と診断 し血装交換療法を主体に治療したが，肺炎，肺らっ血， DIC，消化管出血を合併し 7 日目に死亡した. ウイルス 性劇症肝炎と同様肝に対する治療のみならず，合併症 対策，全身管理が重要である．昏睡VK進行したにも かかわらず救命された例も報告されている17．剖検肝 重量は $750 \mathrm{~g}$ 之萎縮しており, 肝細胞の広沉性部位によ り西広沉性壊死を認め本質的にはウイルス性劇症肝炎 の剖検肝と病理学的には著変を認めなかったが，炎症 性細胞浸潤は乏しかった。本例はアルコール常用者で ありアルコール性の肝組織所見についても検討した が，積極的に支持する所見はみられなかった，さらに アセトフミノフェンの急性中毒として血小板减少性紫
斑病 ${ }^{18)}$ ，心筋障害 ${ }^{19)}$ ，膵障害20)などが報告されている が，本例は臨床経過中 CPK，血中アミラーゼの異常高 值を示していた，病理解剖学的には，心臟左室側壁心 内膜下に心筋の㙹死と軽度の炎症性細胞浸潤がみられ 心筋梗塞の所見であった。また膵蔵には壊死と出血が みられた。これらの所見はいずれる DICに基づくもの と考えられた。

\section{結語}

40歳，女性のアルコール常用者がフルコールととも に, アセトアミノフェン4.8g (セデス $\mathrm{A}{ }^{\circledR}{ }^{\circledR}$ 錠60錠)を服 用し急性肝不全で死亡した 1 例を経験したので報告し た.

本論文の要旨は第16回日本救急医学会総会 (1988年11月, 大阪)和上び第23回日本肝喊学会西部会(1988年12月，大阪） で発表した。

$$
\text { 文 献 }
$$

1）高橋善弥太, 清水 勝, 江崎 治, 他 : 劇莚肝炎の 予後一全国集計一，最新医学 34：2285-2292, 1979

2) Davidson DGD, Eastham WN : Acute liver necrosis following overdose of paracetamol. Brit Med J 2 : 497-499, 1966

3) Gazzard BG, Portmann B, Murray-Lyon IM, et al: Causes of death in fulminant hepatic failure and relationship to quantitative histological assessment of parenchymal damage. Q J Med $44: 616-626,1975$

4）安永 満, 松田彰史, 村田 誠, 他：少量のア七卜 アミノフェン服用に上る急性肝障害の 2 例。肝缄 26 : 493-499, 1985

5) McClain CJ, Kromhout JP, Peterson FJ, et al : Potentiation of acetaminophen hepatotoxicity by alcohol. JAMA $244: 251-253,1980$

6) Barker JD, Carle DJ, Anuras S: Chronic excessive acetaminophen use and liver damage. Ann intern Med 87 : 299-301, 1977

7) Mitchell J, Jollows DJ : Metabolic activation of drugs to toxic substances. Gastroenterology $68: 392-410,1975$

8) Black M: Acetaminophen hepatotoxicity. Gastroenterology $78: 382-392,1980$

9）大西弘生, 武藤泰敏：肝障害の成立々肝の感受性. 日本臨牀 $43: 1114-1120,1985$

10) Prescott LF, Wright $N$, Roscoe $P$, et al: 
Plasma-paracetamol half-life and hepatic necrosis in patients with paracetamol overdosage. Lancet $1: 519-522,1971$

11) McLean AEM, Day PA: The effect of diet on the toxicity of paracetamol and the safety of paracetamol-methionine mixtures. Biochemical Pharmacology 24: 37-42, 1975

12) Wright N, Prescott LF : Potentiation by previous drug therapy of hepatotoxicity following paracetamol overdosage. Scot Med J 18: 56 $-58,1973$

13）野内俊彦, 吉田秀三, 伊藤康紀, 他：少量のアセ卜 アミノフェン (AC) によると考えられる薬剤性肝 障害の 1 例. 肝胆脺 $8: 891-894,1984$

14) Sato $C$, Matuda $Y$, Lieber CS: Increased hepatotoxicity of acetaminophen after chronic ethnol consumption in the rat. Gastroenterology $80: 140-148,1981$
15）阿部晋也，谷口正広，杉山雅俊，他：セデス $\mathrm{A}^{\circledR} に$ ょり急性肝不全, DIC，急性腎不全を合併した 1 症 例. 救急医学 $5: 1601-1603,1981$

16）佐藤千史, 野内俊彦, 蓮村 靖, 他：アセトアミノ フェン肝障害に及ぼす慢性フルコール投与拉よび カフェインの増強作用. アルコール研究と薬物依 存 18 (Suppl) : 22-23, 1983

17）西脇伸二，杉原潤一，中村俊之，他：アセトアミノ フェン大量服用による急性肝不全の一生存例. 肝 藏 $27: 531,1986$

18）児浦純義, 橋口洋一, 寺崎 健, 他：薬物による血 小板減少も認められた紫斑病の 1 例. 臨皮 32 : $641-644,1978$

19) Weston MJ, Williams R : Paracetamol and the heart. Lancet $1: 536,1976$

20) Gilmore IT and Tourvas E: Paracetamolinduced acute pancreatitis. Br Med J 19: 753 $-754,1977$

\title{
An autopsy case of acute hepatic failure caused by ingesting a small dose of acetaminophen in a drinker
}

\author{
Masaru SHImIzU, Hajime Tokita, Yousuke Koshino, Naoki HostYama, Masao Yamada*, \\ Yoshiyata TAKAHASHI** and Yoshiaki NiSHIKAWA***
}

We have experienced an autopsy case of acute hepatic failure caused by ingesting of a single dose (4.8 gr.) of acetaminophen for the purpose of suiside. A forty-year-old-woman was admitted to our hospital in comatic condition. Her clinical course and laboratory data were those of acute hepatic failure. She died 7 days after admission in spite of the therapy of plasma exchange. At autopsy, the liver was markedly atrophic and its weight was $750 \mathrm{gr}$. Microscopically, a massive liver cell necrosis was noted.

It is well known that overdose of acetaminophen induces acute liver injury. However, in this case, the dose of acetaminophen was relatively low ( $4.8 \mathrm{gr}$.). Concerning the cause of the marked liver injury by acetaminophen, following factors may be related; 1 ) the patient had been a drinker 2) acetaminophen was taken together with alcohol and caffein contained in Sedes A. These factors might enhanced acetaminophen-induced hepatotoxicity.

\footnotetext{
* Department of Gastroenterology, Gifu Prefectural Gifu Hospital (Gifu)

** Gifu Prefectural Gifu Hospital (Gifu)

*** Department of Pathology, Gifu Prefectural Gifu Hospital (Gifu)
} 